THE GeneAlogy of THE LABOR HoARding ConcePt

BY JEFF E. BIDDLE

CHOPE WORKING PAPER NO. 2014-13

APRIL 2014

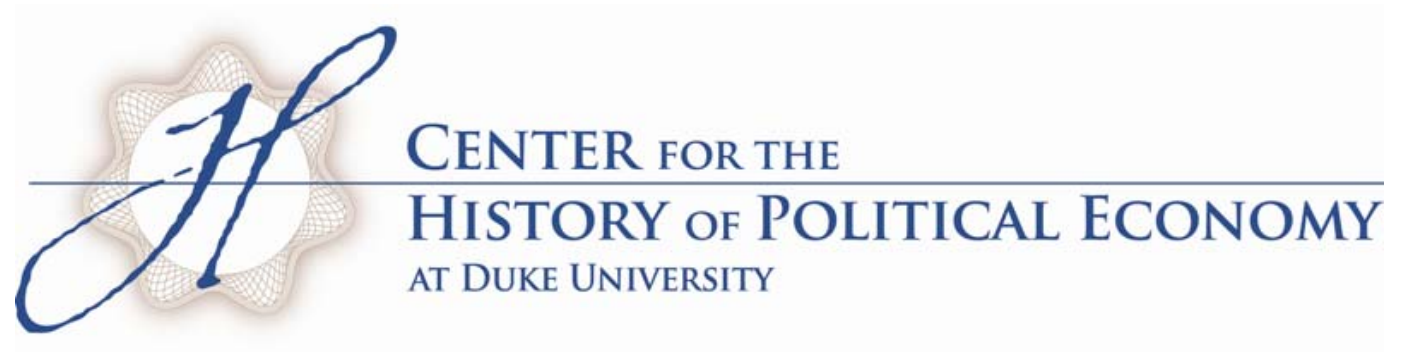




\title{
The Genealogy of the Labor Hoarding Concept
}

Jeff E. Biddle

Dept. of Economics

Michigan State University

April 2014

\begin{abstract}
The modern concept of labor hoarding emerged in early 1960s, and soon became a standard part of mainstream economists' explanation of the working of labor markets. The concept represents the convergence of three important elements: an empirical finding that labor productivity was procyclical; a framing of this finding as a "puzzle" or anomaly for the basic neoclassical theory of the firm, and a proposed resolution of the puzzle based on optimizing behavior of the firm in the presence of costs of hiring, firing, and training workers. This paper recounts the history of each of these elements, and how they were woven together into the labor hoarding concept. Each history involves people associated with various research traditions and motivated by an array of questions, many of which were unrelated to the questions that the modern labor hoarding concept was ultimately created to address.
\end{abstract}

Keywords: labor hoarding, productivity, business cycles

JEL Codes: B2

The catalyst for this paper was a conversation with Dan Hamermesh, who also provided insightful comments on an earlier draft. I would also like to acknowledge useful comments from Roger Backhouse and participants in Duke University's HOPE workshop. 
By the end of the $20^{\text {th }}$ century, the concept of "labor hoarding" had become an accepted part of mainstream economists' explanations of the workings of labor markets and of the relationship between labor productivity and economic fluctuations. For example, the 1999 edition of a popular undergraduate labor economics text included labor hoarding in its glossary of key concepts, defining it thusly: "The practice by which firms retain more workers during recessions than would be technically necessary, specifically overhead workers such as executives, managers and skilled workers on whom the firms have spent large sums to recruit and train" (McConnell, Brue, and MacPherson 1999). The phrase "labor hoarding" had entered this text in its 1989 edition, while the 1986 edition contained essentially the same explication of the phenomenon without the use of the phrase. In all editions, labor hoarding was discussed in a section dealing with cyclical movements in aggregate labor productivity. In the 1980s editions of the undergraduate labor economics texts by Flanagan, Smith and Ehrenberg and by Hamermesh and Rees, labor hoarding was discussed in a chapter on the demand for labor, although in both these texts the link between the labor hoarding phenomenon and procyclical movements of labor productivity was also highlighted. All three texts noted that labor hoarding was a profit maximizing behavior on the part of employers, caused by the existence of costs of hiring, firing, and training workers. In macroeconomics, the 1981 edition of widely used intermediate-level textbook by Dornbusch and Fisher discussed labor hoarding in a section dealing with "Output and Productivity." The section began with the observation that while the neoclassical analysis of earlier chapters implied that labor productivity should move counter-cyclically, measured aggregate productivity actually moves procyclically. Thus an "essential modification of the neoclassical analysis is required," and a recognition of an incentive to hoard labor in response to 
costs of adjusting the labor force was a crucial element of this modification (Dornbusch and Fisher 1981, p. 369).

What I call in this paper the modern concept of labor hoarding was first fully articulated in the early 1960s, and involves the conjunction of three key elements:

A fact: Measured labor productivity (output per worker or per manhour) was procyclical, rising during expansions and falling during contractions. This fact was alternatively represented as an estimated short run elasticity of employment with respect to output of less than unity.

A perceived contradiction between that fact and a widely held theory: In the basic neoclassical theory of the firm in a competitive industry, short run fluctuations in demand are met by increases or decreases in the labor input, with the capital stock unchanged. Given the assumption of diminishing marginal returns to labor, this should lead average labor productivity to move countercyclically, decreasing when output increases and increasing when output decreases.

A possible explanation, rooted in optimizing behavior by firms, and thus consistent with the larger neoclassical paradigm: Costs of hiring, firing, and training employees make it optimal for employers maximizing profits over a longer-term time horizon to keep workers employed in the face of short-run drops in demand. This dampens the amplitude of employment fluctuations in response to demand fluctuations, leading average output per worker (measured productivity) to fall when demand falls. ${ }^{1}$

\footnotetext{
${ }^{1}$ Much of the discussion related to this element was concerned with the appropriate analysis of the costs associated with the labor input. Over the period examined, authors suggested, formally or implicitly, various categorization schemes for labor costs to facilitate such analyses. It was not until the late 1980s that a standard terminology for labor costs began to emerge, with "variable" labor costs referring to costs that change with work time, holding
} 
In a 1985 article that made an influential contribution to the empirical literature on labor hoarding, Jon Fay and James Medoff offered a brief history of the emergence of the labor hoarding concept. Readers were told that until 1960, economists "generally adopted the assumption that the technical production function exhibits decreasing average product of labor in the short run, and that labor is freely variable." This led to the implication that "labor productivity should rise during downturns and fall during upturns." Thor Hultgren "tested this belief' empirically in 1960, and found contradictory evidence. In 1964, Robert Solow emphasized that this was a "puzzle" that it was important for economists to solve, and a substantial literature on the puzzle subsequently developed. According to Fay and Medoff, economists reacted to this either by modifying their prior theoretical assumption, or by questioning the reliability of the empirical finding. On the theoretical side, some economists abandoned their prior beliefs regarding the nature of the short run production function, but the more popular approach was to reject the assumption that labor is a freely variable factor, and embrace the labor hoarding hypothesis.

Fay and Medoff's account correctly identifies key individuals and events, but the larger picture it conveys is quite inaccurate. It is not my purpose, however, to critique Fay and Medoff's review of the literature as they found it in 1985. They were not writing as historians, and providing a reliable narrative of the emergence of the labor hoarding concept was decidedly

\footnotetext{
constant the number of employees (e.g, the hourly wage rate); "fixed" labor costs being those that depend on the number of employees on the payroll (e.g., taxes based on number of workers employed, or, for appropriately defined time periods, salaries); and "adjustment costs" being those associated with changing the size of the labor force but not included in these first two categories: e.g., the cost of hiring a worker (search costs, paperwork) or the cost of training a new worker. These adjustment costs are also associated with labor turnover, as they are incurred each time an employee leaves and is replaced, holding constant the number of employees and hours of work for each employee. Rather than using in a general fashion technical terms that are/were specific to a particular author or time period, I will use the phrases "costs of hiring, firing, and training workers" or "costs of adjusting the size of the labor force", to speak of the sorts of labor costs that were central to all discussions of this third aspect of the labor hoarding concept.
} 
not the goal of their research. I only mention their account because I believe that it portrays the events surrounding the emergence of the modern concept of labor hoarding in the way that most practitioners would expect that they had occurred: an empirical study was conducted to test a well known theoretical hypothesis; the hypothesis appeared to fail the test, and the research community embarked on efforts, both theoretical and empirical, to resolve the apparent anomaly. This rather orderly account of the appearance of and reaction to an anomalous empirical finding stands in interesting contrast to the more complex story I present here. As I will describe below, each of the three elements that were woven together into the modern labor hoarding concept in the early 1960s has a history of its own. Further, the various people involved these three histories were motivated by a diverse set of purposes, worked in a variety of theoretical and methodological traditions, and were often not mainly, if at all, concerned with the questions that the labor hoarding concept was ultimately used to address.

\section{The Discovery of the Fact of Procyclical Labor Productivity}

For the first half of the $20^{\text {th }}$ century, the conventional wisdom among economists was that labor productivity was countercyclical. Three main arguments were offered in support of this belief, none of which involved the assumption of diminishing returns to increases in a homogenous labor input applied to a fixed capital stock. The first was that the rising demand for labor during expansions would force employers to hire lower quality workers, while in a recession the least productive workers would be discharged. The second was that workers were fatigued by long hours typically demanded during economic expansions. The third held that workers would be motivated to work harder when they feared the prospect of job loss, as in a 
recession, and would slack off when labor markets were tight and good alternative jobs readily available.

Wesley Mitchell, in his influential 1913 book Business Cycles, phrased the arguments this way:

Where humanitarian motives are not allowed to interfere with business policy, the less efficient employes (sic) are the first to be discharged after a crisis. Hence the relatively small working forces of depression are the picked troops of the industrial army. When a revival has grown into full prosperity, on the contrary, employers are constrained to accept any help to be had. They must take on men who are too old, and boys who are too young, men of irregular habits, men prone to malinger, even the chronic trouble makers ... A deterioration of the average efficiency of the working force inevitably follows.

... Now overtime labor is especially expensive to employers, not only because it often commands extra rates of wages, but because it is tired labor . . . unable to accomplish as much work per hour as in less busy seasons. . . .

Quite apart from this difficulty of overtime, men cannot be induced to work at so fast a pace when employment is abundant as when it is scarce. Employers complain that in good times their men slow down; employes complain that in dull times they are speeded up. (Mitchell 1913, pp. 477-478)

Mitchell's interest in the cyclical behavior of productivity was linked to his desire to construct a theory of the cycle in which the circumstances that caused contractions were a necessary consequence of the actions of firms in response to prosperity, while economic 
expansions grew out of the circumstances created by the reactions of businessmen to recession. The alleged upward pressure on labor cost per unit of output that took place during economic expansions as labor efficiency declined, and the decline in cost per unit during recession as labor efficiency increased, were important mechanisms in the theory.

Mitchell's methodological convictions compelled him to find empirical backing, if possible, for each element of his theory. As of 1913, however, the only broad based empirical evidence he could offer for his speculations regarding countercyclical labor productivity spoke to the importance of the third argument:

The most trustworthy body of evidence on the subject, however, is contained in the special report made by the Commissioner of Labor in 1904 on The Regulation and Restriction of Output. The evidence is the more convincing because the influence of business conditions upon the efficiency of labor was not a subject of inquiry. Nevertheless, manufacturers and foremen, trade-union officials and manual workers both within and without the ranks of organized labor called attention time after time to the fact that the pace of work was slower in the flush times of 1900-02 than it had been in the dull times of 1894-96. In different phrases they all gave the same explanation - men are less afraid of discharge when business is good. (Mitchell 1913, p.478)

The arguments employed by Mitchell in support of the assumption of countercyclical labor productivity remained common currency among economists for the next few decades. For example, in a 1922 article Paul Douglas explained how the increased demand for labor 
occasioned by prosperity was met by hiring less efficient workers, and spoke of the "breakdown of the fear incentive" during vigorous expansions, which led to more absenteeism, greater turnover, and "served to make the worker less efficient on the job itself." As a result, output per man-hour fell (Douglas 1922, p. 18). During slow economic times, the men who remain employed were the better workers, and "the fear of unemployment serves . . to make men work harder than they did before the period of depression.” (Douglas 1922, p. 21) What makes Douglas's discussion noteworthy is that he supported his arguments with actual productivity statistics reported by various employers during the boom years at the end of World War I and the short, severe recession of 1921. Data from building trade employers in Chicago showed the number of bricks laid per 8 hour day falling from 1500-1600 in 1914-16 to 700-800 in 1918-20, and statistics from Indiana builders showed a similar dramatic decline. In zinc smelting, the labor required to smelt a ton rose by $10 \%$ from 1914 to 1920 . Conversely, output per man-day in Akron's tire factories doubled from the beginning of 1920 to the middle of the recession year of 1921, and data on employment and output that Douglas himself collected from a "middlewestern woodworking plant" showed an increase in output per man-hour of $35 \%$ from the first quarter of 1920 to the first quarter of 1922.

In the mid-1920s, the Bureau of Labor Statistics (BLS) began to publish systematic measures of labor productivity for a large number of industries, but the time series that they constructed were short, and the steep upward trend in labor productivity revealed by the numbers dwarfed (both on paper and in the minds of economists) any possible cyclical movements. Much attention was focused on explaining the trend, and even more on worrying over its possible consequences, with the data touching off a large literature on technological unemployment. With the onset of the Great Depression the BLS labor productivity indexes began to fall, but it was not 
clear whether this was something that typically occurred in slumps or a special consequence of this particularly severe contraction. The bulk of the attention, however, was on whether the rapid productivity increases of the 1920s might have somehow contributed to the depression and/or slowed the recovery (Woirel 2006).

During the 1930s, the BLS continued to collect the industry level data required for constructing labor productivity measures, but the serious analysis of these data, both their reliability and their implications, was taking place at the National Bureau of Economic Research (NBER). ${ }^{2}$ The research program of the NBER, from its founding in 1922 through at least the end of World War II, was very much a reflection of the priorities of its cofounder and first director of research, Wesley Mitchell. Mitchell, a charismatic man and one of the most respected economists of his generation, had a vision of building an empirically based body of economic theory sufficiently reliable to serve as the basis for designing effective economic policies. At the same time, the NBER provided Mitchell with the resources necessary to pursue his own empirical business cycle research agenda. ${ }^{3}$ The NBER's work with productivity statistics served both ends: evidence on longer term trends in labor productivity was relevant to a wide range hypotheses about the causes and consequences of technological change, among other things; while evidence on movements of labor productivity over the cycle could be used to test one of the key mechanisms in Mitchell's original cycle theory, as described above.

However, a hurdle stood in the way of coming up with reliable generalizations about the behavior of labor productivity over the cycle: The most dependable measures of output and employment came from the censuses of manufactures, which were conducted every five years up

\footnotetext{
${ }^{2}$ Mills (1933) and Jerome (1934) report on early NBER research projects concerned with measuring and analyzing productivity statistics. In 1937 the Bureau received a grant from the Maurice and Laura Falk Foundation that was used to launch a major program on the measurement of production and productivity (NBER 1938, p. 29).

${ }^{3}$ See Biddle (1998) on the relationship between Mitchell's conception of the social role of economic research, his own research agenda, and the program of the NBER.
} 
to 1919 , then biennially thereafter. Annual and even monthly series could be constructed from these numbers using "interpolating indexes", but the careful empiricists at the NBER were rightly nervous about deriving strong conclusions from such interpolated data. ${ }^{4}$ As a result, most of the analyses of productivity changes coming out of the NBER in the 1940s and 1950s dealt with long term trends.

Still, NBER researchers were beginning to see patterns in the data that contradicted the conventional wisdom that labor productivity was countercyclical. Thor Hultgren, assigned by Mitchell to study the cyclical behavior of the transportation sector, examined annual data from the railroad industry, and concluded that "From 1921 onward, the productivity of labor, defined as traffic units per man-hour, rose in every expansion, fell in every contraction" (Hultgren 1948, p. 182). Mitchell, after seeing Hultgren's results, wrote to his NBER colleague and coauthor Arthur Burns that "Thor virtually demolishes the notion to which I attached so much importance in 1913 that unit costs encroach upon profits late in expansion, and are materially reduced in late contraction - so far as railway transportation is concerned. He leaves mere remnants of the idea, and makes me wonder whether it has much validity in other types of business." ${ }^{, 5}$ In his posthumously published What Happens During Business Cycles, Mitchell acknowledged the existence of "two sets of cyclical fluctuations," in labor productivity, "one positively, the other inversely, related to production." The forces listed as contributing to an inverse relationship were those Mitchell had initially noted in 1913, while the main factor cited as making for a positive relationship was the view, not uncommon in the postwar years, that "modern plants attain their highest technical efficiency when operated steadily at the capacity for which they were designed." An expansion brought actual output steadily closer to that capacity, and perhaps a

\footnotetext{
${ }^{4}$ See for example, Hultgren (1960, p. xv).

${ }^{5}$ Mitchell to Burns, June 16, 1946, quoted in Burns (1952, p. 53).
} 
little beyond it, so that measured labor productivity rose through most of the expansion. In recessions output fell below optimal capacity, dragging down labor productivity. Thus, something in the nature of the short-run production function contributed to procyclical labor productivity. Although Mitchell noted that "Fluctuations in employment as reported by the Bureau of Labor Statistics are usually slighter than the corresponding fluctuations in production", limitations of the available data left him unwilling to make a strong statement about whether the positive or inverse relationship dominated in the economy as a whole (Mitchell 1951, pp. 132-133).

The NBER's official announcement of the reality of procyclical labor productivity came in the 1959 Occasional Paper Basic Facts on Productivity Change, with NBER Director of Research Solomon Fabricant declaring that "Over the whole period since 1889, productivity fluctuated with the state of business. Year-to-year rises in productivity were greater than the long term rate when business was generally expanding, and less, or often falling when business was generally contracting" (Fabricant 1959, p. 10). Fabricant based this conclusion mainly on further research by Hultgren, which was published in 1960 in Hultgren's book Changes in Labor Cost during Cycles in Production and Business. In the book's Forward, Geoffrey Moore promised the reader that Hultgren's results would be "highly useful" for business cycle analysis, noting that "The cyclical behavior of labor cost per unit of output ... has heretofore been dealt with largely on a speculative basis" as the "quantitative facts on the subject" had long been "scanty" (Moore in Hultgren 1960, p. xiii). Hultgren opened by reiterating Mitchell's (1951) discussion of the factors making for procyclical and counter-cyclical labor productivity. If the course of labor productivity over the cycle was an empirical question, however, Hultgren's data revealed a fairly 
robust answer: "Hours per unit usually fall when production rises, and vice versa" (Hultgren 1960, p. 6).

Hultgren used statistical methods that had been developed at the NBER over the previous two decades for business cycle analysis. ${ }^{6}$ Using the monthly output series for industries for which he had adequate data, Hultgren identified the peaks and troughs of each industry's "specific cycles". He then calculated the change in labor hours per unit of output (the reciprocal of output per man-hour) for each peak to trough period (contraction) and each trough to peak period (expansion). Pooling data across industries, Hultgren reported that

In one industry or another, at one time or another, we have data on ninety expansions of production and ninety-nine contractions. In eighty-three, or 92 percent, of the ninety expansions, there was a net decline in hours per unit. In seventy, or 71 per cent, of the ninety-nine contractions, there was a net rise in hours per unit. The pooled data suggest a strong tendency toward an inverse relation between hours per unit and total output (Hultgren 1960, p. 8).

Hultgren extended this basic analysis in several different directions. He limited the sample to industries with four or more cycles. He expanded the sample to include all industries for which reliable annual data could be found, marking peaks and troughs by year instead of by month. And he examined the movement of hours per unit between the peaks and troughs that emerged when the data from all industries were aggregated into a single output series. Nothing changed the basic story of strong inverse relationship between hours per unit and output, although he did note that the inverse relationship tended to break down in the final months of expansions.

\footnotetext{
${ }^{6}$ See Burns and Mitchell (1946) for detailed descriptions of these methods.
} 
The forward to Hultgren's book included the following footnote:

After this paper had gone to press, the report by Edwin Kuh, "Profits, Profit Markups, and Productivity" ... became available. This interesting analysis utilizes the national income accounts to develop quarterly estimates of output per man-hour and wage and salary costs per unit of output for the corporate sector of the economy. On most of the points that overlap, the conclusions of Kuh's and Hultgren's studies appear to be consistent, which is reassuring in view of their independent statistical foundation. (Moore in Hultgren 1960, p. xvii)

The data used by Kuh in his report were indeed different from those used by Hultgren, and Kuh's statistical methods differed from Hultgren's as well. Kuh's output series was the deflated value product generated by the corporate sector, quarterly, from 1947-1957. To construct a corresponding labor variable, he started with annual data on employment in the corporate sector, then interpolated quarterly employment totals using quarterly industry level employment data, with each industry's data adjusted by the portion of that industry's workforce employed in the corporate sector. Multiplying the employment series by quarterly data on average weekly hours from the BLS resulted in a quarterly man-hour series. Kuh's method of determining the cyclical behavior of labor productivity was to regress output per man-hour on the level of output and a trend, explaining that "for want of a better device to measure long run technological change, the commonly employed practice of introducing a linear trend term to represent this has been followed. To measure short-run effects on output per man-hour when capital stock and techniques are assumed fixed, the level of output itself was introduced." The coefficient on 
output was positive and significant: labor productivity rose with output. However, Kuh cautioned that "This equation should only be expected to hold within a given range of output, since diminishing returns would cause a decline in output per man-hour for extremely large levels of output with given capital stock and labor force" (Kuh 1960, p. 85).

That Kuh's choices about data and empirical methods differed from Hultgren's reflects the fact that Kuh was part of a different research program and was motivated by different purposes. Kuh was one of a number of economists of the time working on building macroeconometric models. A central purpose of these models was to generate more accurate forecasts of key macroeconomic variables and measurements of important macroeconomic relationships, both of which would provide a more reliable foundation for economic stabilization policies. ${ }^{7}$ For the most part these economists worked with a Keynesian theoretical framework, and their methodological guideposts were those laid out in Haavelmo (1944) and embodied in the work of the Cowles Commission econometricians of the late 1940s and early 1950s:

Economic models should be expressed as systems of non-deterministic equations and be based in economic theory; the parameters of the equations should have well defined theoretical or policy relevance; and the form of the equations and the (explicitly specified) assumptions about their non-deterministic elements should allow for both the estimation of numerical values of the parameters and the application of classical statistical inference methods to the estimates.

Kuh was the first of several of these technocratic Keynesians who would demonstrate the existence of procyclical labor productivity in the early 1960s, including Neild (1963), who did so by using quarterly data from the UK and Ronald Soligo (1963) in his Yale doctoral dissertation.

\footnotetext{
${ }^{7}$ For example, Kuh's research on productivity movements was part of his work on the Brookings-SSRC Quarterly Model of the US Economy, and his findings were first presented in a paper prepared for the Joint Economic Committee of the US Congress, a committee charged with developing policies to maintain full employment and price stability, as mandated by the Employment Act of 1946.
} 
Work by Brechling (1965) and Eckstein and Wilson (1964) could be mentioned as well. For the most part, these economists did not articulate their motivation in terms of understanding the behavior of productivity over the cycle, but in terms of discovering or better modeling the short run relationship between employment and output, often for the purposes of producing more accurate forecasts. ${ }^{8}$ It became common to represent the relationship with the coefficient on current period output in an employment regression, i.e., a short-run elasticity of employment with respect to output, as Soligo (1963) termed it. These authors understood that a value below 1 for this elasticity implied procyclical labor productivity; it was just that the behavior of labor productivity was not the central focus of their work.

By the early 1960s, then, procyclical labor productivity was a well-accepted fact. For example, Robert Solow, in his 1964 presidential address to the Econometric Society, "On the Short Run Relationship Between Employment and Output", announced that "Generally speaking, productivity rises most rapidly when output is recovering toward capacity and falls or rises least rapidly during recessions. The effect appears both in British and American manufacturing statistics, but is rather more pronounced in Britain" (Solow 1964, p. 6). In 1962, Arthur Okun, presenting a paper to the American Statistical Association, informed his audience that "The record clearly shows that man-hour productivity is depressed by low levels of utilization, and that periods of movement towards full employment yield considerably above average productivity gains" (Okun 1963, p. 6). And readers of Eckstein and Wilson's (1964) paper, in circulation since 1961, were informed that Hultgren's findings of a positive relationship between changes in output and changes in productivity at the 3-digit industry level were

\footnotetext{
${ }^{8}$ See, e.g., Neild (1963, p. 1) or Brechling (1965, p. 211); Eckstein and Wilson (1964) is an exception to this generalization.
} 
consistent with the characteristic behavior of productivity over the general business cycle, as had been confirmed by several other researchers using different techniques and different data.

\section{The Labor Hoarding Concept Emerges}

Okun's 1962 paper for the American Statistical Association includes an articulation of the labor hoarding concept involving all three of the components identified in the introduction: acceptance of the fact of procyclical (measured) labor productivity, understanding of the contradiction between the fact and basic neoclassical theory, and a possible explanation of the contradiction rooted in an analysis of how costs of hiring, firing, and training workers affect a firm's optimal employment strategy. It is the earliest such articulation that I have found. After asserting the existence of procyclical productivity, Okun goes on to point out that:

The implications and explanations of this phenomenon are intriguing. Indeed, many a priori arguments have been made for the reverse view - that depressed levels of activity will stimulate productivity through pressure on management to cut costs, through a weeding out of inefficient firms and low quality workers, and through availability of more and higher quality capital per worker for those who retain their jobs. If such effects exist, the empirical record shows that they are swamped by other forces working in other directions. (Okun 1963, p. 6)

Note here that among various a priori arguments for procyclical labor productivity we find reference to the key mechanism that drives cyclical movements of labor productivity in the basic neoclassical theory of the firm in the short run: the quantity of capital per worker. Okun then 
offers some "speculation" on the matter, expressing the hope that researchers will further study the problem with "concrete evidence at a microeconomic level":

...the positive relationship between output and labor productivity suggests that much of labor input is essentially a fixed cost for fairly substantial periods. Thus high output levels permit the spread of labor overheads, and low production levels raise unit fixed costs of labor. At times we may take too seriously our textbook examples which view labor as a variable factor, with only capital costs as fixed. Even the most casual empiricism points to an overhead component in labor costs. (Okun 1963, p. 6)

Okun listed many reasons why employment "may not be easily variable", including "Transaction costs associated with laying off labor and then, in the future, doing new hiring ..." and "Acquired skills that existing employees have learned on the job may make them particularly valuable to the firm, so that it pays to stockpile underemployed labor rather than run the risk of having to hire untrained men when business conditions improve ..." (Okun 1963, p. 7).

Two years later, in his presidential address to the Econometric Society, Robert Solow's recognition of the procyclicality of labor productivity was also accompanied by the two other components of the labor hoarding concept. Solow's reference to the relationship between neoclassical theory and the short run movements of labor productivity comes in the context of a discussion of an earlier pair of studies showing that the average real wage in the economy was positively correlated with the level of aggregate output (Dunlop 1938; Tarshis 1939). These studies were intended as empirical tests of Keynes's assertion that money wages and real wages 
would move in opposite directions over the cycle, and they presented fairly convincing evidence that this was not the case. But Solow recognized, as had Dunlop before him, that this test of Keynesian theory was also a test of neoclassical theory, as Keynes's model of the demand side of the labor market in The General Theory was neoclassical in nature, and had implications for the cyclical movement of labor productivity as well as real wages:

... the system of that book, and the mathematical reformulations that followed it, contained a short-run relationship between aggregate output and employment. Whether one thinks of this relation as showing the result of applying more and more labor on an essentially homogeneous stock of capital, or the result of calling less and less efficient plants into production as output and employment increase, the effect is the same. The slope of this relation plays the role of the marginal product of labor, and the marginal product of labor diminishes as employment increases in the short run. Thus Keynes, like a good student of Marshall and Pigou, argued that any increase in employment in the business cycle had to be associated with a decrease in the real wage ... (T)he reasoning that led Keynes to his assertion about the cyclical behavior of real wages leads equally to the prediction that output per man must fall - or rise slower than trend - during business cycle upswings and rise - or rise faster than trend - during downswings or decelerations (Solow 1964, p. 5-6). 
Solow described three mechanisms that had been proposed to explain what he called the "perverse behavior of productivity in the short run", explicitly giving one of them the "labor hoarding" label:

The labor hoarding mechanism operates on the assumption that important costs are associated with changes in the level of employment and with the risk that trained workers laid off as output falls may not be available as output rises again. It can be shown that a long run cost-minimization policy may require that even if labor-requirements per unit of output fall with output, employment per unit of output may well increase as recession sets in. (Solow 1964, pp. 7-8; emphasis in original). ${ }^{9}$

Solow argued that the labor hoarding mechanism was closely related to what he called the "decreasing cost" mechanism, which "rests on the hypothesis that much labor in modern industry is "overhead" in character, and can be thought of as a fixed factor in the short run." The two mechanisms "blend into one another. Even overhead labor is not eternally fixed; many of the characteristics which lead employers to hoard labor are precisely those which give some labor its quality as overhead." Solow thus chose to "use the term labor-hoarding as a catch-phrase to stand for all the frictions involved in meeting transitory variations in output with variations in employment" (Solow 1964, p. 8). In the econometric models presented in the address, these frictions were represented by a standard partial adjustment equation for employment; and at one point he referred to an earlier version of the paper (presented in September of 1963) in which he

\footnotetext{
${ }^{9}$ Solow supports the claim "It can be shown" by citing his own paper "Distribution in the Long and Short Run ... prepared for International Economic Association Conference on the Distribution of National Income, Sept. 1964."
} 
had derived such a partial adjustment equation from a model in which employers faced fixed costs of adjusting employment and minimized "cumulated costs over a fairly long period" (Solow 1964, p. 20). ${ }^{10}$

By 1966, the modern labor hoarding concept was being taught to graduate students at Yale and presumably at other major economics graduate programs as well. ${ }^{11}$ The phrase used in its modern sense made its first appearance in a major economics journal in 1968 when R. J. Gordon used it to explain why productivity movements in the construction industry are countercyclical, while they are procyclical in manufacturing: "In manufacturing, on the other hand, measured productivity tends to decline during business slumps, probably because labor hoarding is more prevalent than in construction, where small entrepreneurs cannot afford to pay skilled workers when there is no work to be done." (Gordon 1968, p. 419). The nature of the usage, without definition or elaboration, shows that Gordon and the journal editor assumed that the audience would have a shared understanding of the meaning of the phrase.

\section{Pro-Cyclical Labor Productivity and Neoclassical Theory}

For Robert Solow, the newly discovered fact that labor productivity rose in expansions and fell in contractions was "perverse" because it seemed to contradict a fundamental assumption of the basic neoclassical theory of the firm. It would be inaccurate, however, to say that Solow's perception of the relationship between the cyclical behavior of labor productivity and economic theory was shared by all or even most of the economists working during the fifties

\footnotetext{
${ }^{10}$ The partial adjustment model for short term employment begins with the equation $E_{t}-E_{t-1}=\gamma\left(E_{t}{ }^{*}-E_{t-1}\right)$, where $E$ is employment (or its $\log$ ), $\mathrm{E}_{\mathrm{t}}{ }^{*}$ is desired employment, and $\gamma$ is the partial adjustment parameter. Then $\mathrm{E}_{\mathrm{t}}{ }^{*}$ is replaced with an equation describing desired employment in terms of observable variables, which Solow derived by inverting a Cobb-Douglas production function. This leads to an estimable equation in which the change in employment is regressed on output, the capital stock, lagged employment, and a trend. In the logged version of the model, the coefficient on output is the short-run elasticity of employment with respect to output.

${ }^{11}$ Personal communication with Dan Hamermesh.
} 
and the early sixties on productivity measurement or estimation of the short-run relationship between employment and output.

Neither Fabricant nor Hultgren at the NBER pointed out the contradiction between the NBER's findings regarding labor productivity and the implications of the neoclassical assumption of diminishing returns to labor in the short run, and this is not surprising. Fabricant had no particular commitment to neoclassical theory, and in this he was following in the footsteps of Wesley Mitchell, for whom the neoclassical tradition represented just one of a number of types of economic theory, each potentially useful for generating insights into economic activity. Mitchell had believed that the way to improve economic theory was to weave together elements derived from the various existing theoretical frameworks in economics, but only after a careful use of statistical data to test, and if necessary modify, relevant hypotheses derived from those frameworks. As we have seen, in the early $20^{\text {th }}$ century economists had a number of reasons, most unrelated to the formal neoclassical theory of the time, for believing that labor productivity was countercyclical, and Mitchell saw in this a potentially important factor underlying the business cycle. This made the identification of the actual path of labor productivity over the cycle, and any corresponding movements in costs and profit margins, a high priority activity in the NBER's business cycle program, and it was within this context that Hultgren assessed the significance of his results.

The macroeconometric model builders working on the short-term relationship between employment and output displayed a range of attitudes regarding the theoretical implications of the patterns they were uncovering. Neild (1963) made his position towards theory clear: His first priority was to produce better forecasts for policy makers. Both "traditional" and "imperfect competition" theories, he argued, assumed that employment would fall proportionately with 
output; but that was not what happened in the UK. This "gap in theory" was causing problems for macroeconomic forecasters. "We do not want to prove or disprove any theory", he explained, "but to find relationships which work" (Neild 1963,p. 1). A somewhat more sophisticated version of the idea of a gap in theory was expressed by Kuh in a 1965 paper, in which he attempted to estimate both short-run and long run elasticities of employment with respect to output by including lagged values of output in his employment regressions. In summarizing his results, Kuh commented that:

...the long run elasticity of demand for labor with respect to output might be less than unity - given the stock of capital - so that labor productivity will rise secularly on that account in a decidedly non-neoclassical fashion. As matters turn out, the long run parameters do not conflict with neoclassical assumption in some instances although they do in others. However, the behavior of lagged responses does indeed lead to conclusions strongly at variance with neoclassical reasoning which should be a cause of neither congratulation nor concern since the business cycle has been excluded by choice from that domain of analysis.” (Kuh 1965, p. 9)

Thus, procyclical labor productivity was not to be regarded as a challenge to or contradiction of neoclassical theory, but as irrelevant to it. ${ }^{12}$

\footnotetext{
${ }^{12}$ A similar attitude was displayed by Brechling (1965, p. 188), who began constructing his econometric model of the short-run employment-output relationship by assuming "imperfect competition and administered prices" and commented that he did not believe that cost minimization "or any other motivation" could be assumed over the short periods he was studying.
} 
In his 1964 address, however, Solow clearly framed procyclical labor productivity as a challenge to economic theory, explicitly rejecting the attitude that "finding relationships that work" for forecasting was more important than resolving such challenges, as well as arguments that sidestepped the apparent challenge with appeals to the necessity of theoretical pluralism in economics:

I know it will be as obvious to you as it is to me that I have not solved the problem of giving a good theoretical explanation of short-run productivity behavior. I hope it will be as obvious to you as it is to me that this is a problem worth solving. Its importance goes far beyond the desirability of being able to predict how output per man-hour will change from this quarter to the next. Art Okun or Ed Kuh or Dan Suits can already do that. What I am looking for is a way to unify the economics we teach our students and the economics we use when we advise governments and analyze passing economic events, and do it in a way amenable to econometric treatment. This patching up of theory to explain experimental or statistical uniformities is the way science usually proceeds. (Solow 1964, pp. 29-30, skipping inserted page 29a)

That Solow considered a "good theoretical explanation" of the "perverse" behavior of labor productivity to be one consistent with the neoclassical framework is apparent from the fact that all the models he proposed in his address involved the assumption of optimization (cost minimization) and a long run production function with the standard neoclassical properties of diminishing marginal returns to labor and capital. Solow made at least two other references in the 
address to the desirability of unifying economic theory (pp. 13, 19), and in wishing for such a unification under a neoclassical umbrella was expressing an attitude that would soon become a dominant one in the profession.

\section{Costs of Hiring, Firing, and Training Workers make “Labor Hoarding” an Optimal}

\section{Response to Short Term Fluctuations in Demand}

As we have seen, by the time Solow addressed the Econometric Society in 1964, speculation that the recently discovered procyclical labor productivity was a manifestation of various "fixed" or "overhead" costs associated with labor was prevalent. Okun (1963) had provided a list of such costs, as had Kuh (1960) and Soligo (1963). ${ }^{13}$ But discussions of these sorts of costs, and assertions that they would or should influence the response of a profit maximizing employer to variations in demand for his product, actually had a long history in economics, going back at least to the scientific management movement of the early $20^{\text {th }}$ century.

The rhetoric of the scientific management movement had a progressive, idealistic strand that envisioned the amelioration of many of the problems facing the industrial worker via the voluntary adoption by enlightened business owners (advised by enlightened engineers) of personnel management policies that were rational, fair, and also beneficial to the bottom line. Herbert Hoover's broad approach to economic policy had its roots in this ideology (Barber 1985). In the early 1920s, then-Commerce Secretary Hoover convened a "Conference on Unemployment," one component of which was a study by the NBER of the important facts regarding business cycles and unemployment. One aspect of the NBER project was research into

\footnotetext{
${ }^{13}$ Okun's list, for example, included "contractual commitments" (contractual terms of employment, severance pay); "technological factors" ( indivisibilities in the production process that prevented certain types of labor input from being varied proportionately with the variation in output); "transaction costs" associated with laying off labor, and then doing new hiring in the future; "acquired skills", or specific human capital that might be lost if the worker could not be rehired after layoff; and "morale factors". (Okun 1963, pp. 6-7)
} 
policies already adopted by successful firms to "stabilize" employment in the face of seasonal and cyclical fluctuations, as it was hoped that wider knowledge of such policies would spur wider adoption. The quote below comes from a chapter in the NBER study by N.I. Stone, a Ph.D economist who was at the time an executive for clothing manufacturer Hickey Freeman:

Apart from the social injury which intermittent production causes, a broad view of the ultimate interests of the individual manufacturing concern discloses the disadvantages of intermittent production and the gains that would flow from continuous operation ... Business men now recognize the wastefulness of a large labor turnover, the expensiveness of training new help, and their inefficiency and resultant high cost, even when hired at comparatively low wages. The increased costs of production during the period of "tuning up" a plant to its state of efficiency, is an item familiar to every industrial engineer and plant manager. Added to these is the loss of the more capable and ambitious workers who drift away during periods of idleness to more steady occupations unless held by the inducement of higher rates of wages than would be necessary to satisfy them under steady employment . . .

These considerations have prompted a small but growing number of concerns to devise means for keeping plants in continuous operation despite the intermittent consumers' demand (Stone 1923, p. 117).

Stone went on to describe methods employed by various firms to stabilize employment, which included labor hoarding strategies like "manufacturing to stock" and transferring "surplus help from one operation or department to another." 
Economists were able to see these ideas discussed more fully in a neoclassical framework in J. M. Clark's book Studies in the Economics of Overhead Cost. J. M. Clark, son of pioneering American marginalist John Bates Clark, was one of a small number of economists of his day well versed in the marginal productivity theory of value and distribution. However, the younger Clark was less interested in further developing that theory and more interested in talking about dynamic aspects of the macroeconomy, and in describing policy implications of what we would today call market failures. A central theme of Clark's book was that the existence of overhead costs often led to situations in which the private costs and benefits of various business decisions deviated from their social costs and benefits. A chapter on "labor as an overhead cost" developed the concept of a social overhead cost to maintaining a healthy and properly trained labor force, employing the idea to highlight the social waste associated with unemployment. Clark also explained, however, that some labor costs were overhead costs from the employer's point of view as well. Some workers were salaried, and it was often desirable to "keep a nucleus of the working force together through a period of depression" so as to avoid "the cost of building up the force again when business revived" because "when new men are taken on, there is waste in teaching them" and "there are certain key men whose experience . . . is so valuable that they cannot be laid off without heavy loss". Clark used numerical examples to show how these considerations affected the profit maximizing businessman's responses to seasonal and cyclical demand fluctuations. (Clark 1923, pp. 43-44, 50-51, 92, 94, 160, 184-186). He concluded, however, that the marginal social cost associated with a layoff still exceeded considerably the costs borne by the individual employer, so that the employment reductions undertaken by businessmen in the face of reductions in demand, while tempered by considerations of the overhead costs associated with labor, would still exceed the socially optimal level. ${ }^{14}$

14 “The effectiveness of financial self interest as a motive to regularizing production depends on how closely the 
Clark did not use mathematical or graphical models in the book; his logic was expressed verbally and he sometimes made complex points rather tersely. Still, it was a widely read book among economists, going through seven printings over the next 25 years, and it seems likely that the idea of adopting hiring policies to take account of employment adjustment costs remained alive among economists as well as the intellectual descendants of the scientific managers. One piece of evidence that it did is found in a newspaper column written by Walter Lippmann. Lippmann, whose columns were aimed at an educated, elite audience, wrote frequently on topics related to economic policy, and based his economic opinions on consultations with a wide network of prominent economists (Goodwin, 2014). Writing in 1936 about the likelihood that America would restore full employment, Lippmann noted that "after careful inquiries", he had determined that the economy was in the phase of recovery where that restoration was imminent:

The fundamental fact seems to be that up to the recent months re-employment has lagged behind recovery. The reason for that seems now to be clear . . (M)ore men were kept at work in the bad times than were actually needed. So until recently the recovery has consisted mainly in increasing the work of men who had kept their jobs. But within the past six months or so, these men have again become fully employed. Then only could the process of re-employing the completely unemployed begin (Lippman 1936).

differential costs borne by the employer correspond to the true differential costs of added production to the industrial community as a whole, and how closely the residual or constant costs of the employer correspond to the burdens which the industrial community must bear whether production is maintained or not." (Clark 1923, p. 167). The point that businessmen's self interest is not enough to lead to the socially optimal employment responses to business cycles is found on pp. 169-170 and elsewhere. 
Interestingly, however, when the phrase labor hoarding itself began to be used by economists and business journalists to describe the business practice of maintaining a labor force larger than technically necessary to produce current output, the practice was being condemned rather than lauded. During WWII, as the governments of the US and the UK were attempting to meet the demands of wartime production, they found themselves frustrated by the labor hoarding of manufacturers responding to high, but uneven, war-related demand:

There has been, of course, a good deal of labor hoarding in certain industries, and a considerable amount of wasteful use of labor during the period when war plants were being staffed. . . the tendency on the part of employers to take out "manpower insurance", that is, to hire more workers than were currently needed in anticipation of future requirements, and as a protection against a high turnover rate - has been pronounced (Haber 1944, p. 61).

In the mid fifties, labor hoarding by managers in the Soviet Union was cited as a reason for higher measured unemployment in, but also the greater efficiency of, western economies (Seigel 1953, Oxenfeldt and van den Haag 1954). By the sixties, however, the pendulum was swinging back, and labor hoarding was again being seen as a sound and beneficial business practice. A. J. Brown (1958), in his presidential address to the Royal Economic Society, credited labor hoarding with keeping the British unemployment rate surprisingly low after the war. The UK's National Joint Advisory Council of the Ministry of Labour, while admitting that inefficient "labor hoarding" might sometimes occur, concluded that: 
"labour hoarding" ... is less common than is often supposed, and that where it does occur there are often good reasons for it. Sometimes what is called "labour hoarding" may simply be the reluctance of an employer to disband a trained labor force until it is clear that there is no early prospect of his being able to employ it fully. This may well be sensible both from the point of view of manpower and from that of personnel policy. (UK Ministry of Labour, 1962, p. 47).

\section{Formalization}

The relatively rapid and widespread acceptance among economists of the proposition that costs associated with adjusting the labor input were a likely reason for procyclical labor productivity owed much to the appearance in the early 1960s of a pair of formal models characterizing the firm's demand for labor over a multi-period time horizon. One was in the book Planning Production, Inventories, and Work Force by Charles Holt, Franco Modigliani, John Muth, and Herbert Simon (1960, hereafter HMMS); the other in Walter Oi’s 1961 doctoral dissertation, first published in his 1962 article "Labor as a Quasi-Fixed Factor.” Each model represented the firm's decision regarding the number of workers to hire in each of several future periods as a mathematical optimization problem. Oi assumed hiring and training costs associated with adding a new worker; HMMS described these plus various other costs associated with changing the size of the work force. Both models implied that changes in product demand would not be met by proportional changes in the demand for labor. Neither HMMS nor Oi, however, mentioned the implications of their model for the cyclical behavior of labor productivity.

Planning Production, Inventories, and Work Force was written while the authors were affiliated with the Graduate School of Industrial Administration (GSIA) at Carnegie Tech. The 
book was not presented as a contribution to the positive theory of the firm, but as a normative analysis of what the profit maximizing manager should do in the presence of uncertainty regarding future demand, with the obvious implication that while some managers may be optimizing, many are not. At the book's core was a mathematical model described thusly: "our problem ... (is) . . to minimize $\mathrm{C}_{\mathrm{T}}$ subject to the relations Eqs. [4-2], with respect to the decision variables $\left(\mathrm{W}_{1}, \mathrm{~W}_{2}, \ldots\right)$ and $\left(\mathrm{P}_{1}, \mathrm{P}_{2}, \ldots\right)$ for any given initial conditions (inventory and work force) and an arbitrary known or estimated pattern of future orders." $\mathrm{C}_{\mathrm{T}}$ was the sum of costs over a multi-period planning horizon, eqs. [4-2] described the evolution of inventories, $\mathrm{W}_{\mathrm{t}}$ was the workforce in period $t$, and $\mathrm{P}_{\mathrm{t}}$ production in period $\mathrm{t}$ (Holt et al., 1960, p. 93). The optimal decision rules implied by the model were derived using the calculus of variations, and readers were provided with strategies for estimating the parameters of the model's quadratic cost function and for creating forecasts of future demand, both of which were necessary to implementing those rules. This mode of presentation was in keeping with the GSIA mission of training managers to apply modern quantitative methods to business decisions.

It is clear, however, that the book's model was an outgrowth of both Modigliani's and Simon's longstanding research on positive theory of decision-making under uncertainty, and the model's structure represented its authors' commitment to the methodological precepts of the Cowles Commission, which called for the development of mathematically rigorous models amenable to econometric estimation. ${ }^{15}$ The book included a proof of an important "certainty equivalence" result: given a quadratic cost function, the optimal decision rule from a version of the model that took into account the full probability distribution of the path of future orders was

\footnotetext{
${ }^{15}$ Holt was a Keynesian economist with an engineering background, and Muth was a graduate student. The fact that the decision model took the form of a neoclassical optimization model reflected Modigliani's analytical preferences. The story of Simon and Modigliani's activities and interactions leading up to the development of the HMMS model is told in Rancan (2013).
} 
the same as the optimal decision rule derived from a version of the model that treated the expected value of orders in each future period as the actual future value. Judged by the standards of the economics profession of the time, the HMMS model and the statistical methods recommended for implementing it were quite technically demanding.

In deriving the cost function to be minimized in the selection of work force and production levels, and describing the sorts of information needed by managers to estimate it, HMMS mentioned several items that had become common in discussions of overhead or fixed costs of labor, describing them under the broad headings "Hiring and Training Costs", "Layoff Costs", "Overtime Costs", and "Idle time" costs. ${ }^{16}$ More important to the authors' presentation than the precise categorization or analysis of each of these cost items, however, was the argument that their aggregate impact on labor cost could be approximated by a quadratic cost function. i.e., one that included linear and quadratic terms in the size of the work force, the oneperiod change in the size of the workforce, and the level of output (Holt et al. 1960, chapt. 3).

In the authors' discussions of the relationship between labor costs and size of the work force, the only hint of the concept of the diminishing marginal productivity of labor in the short run was a reference to increased costs of supervision, bottleneck delays, scrap costs, etc. when the workforce was increased in order to raise production levels. And while the authors showed that, for a given path of future orders, the implementation of the model's optimal decisions rules would lead to a reduction in the fluctuations of both output and employment, the impact of this on the behavior of output per worker was not discussed. (Holt et. al 1960, pp. 18-20).

Walter Oi's 1961 approach to analyzing the impact of "fixed" costs associated with labor differed from that of HMMS in a number of ways. Many of these differences can be understood

\footnotetext{
${ }^{16}$ The authors indicated that they were simply summarizing a discussion found in a 1956 issue of the Journal of Industrial Engineering, thus linking their work to the Scientific Management tradition discussed above.
} 
as consequences of the fact that Oi wrote his dissertation at the University of Chicago, where at this time students were taught an approach to economic analysis distinct from that preferred by the HMMS team. Perhaps the best known methodological precepts of this "Chicago view" are found in Friedman's (1953) essay on "The Methodology of Positive Economics": Theories are to be judged not by the descriptive realism of their assumptions, but by the accuracy of their predictions; and that, as a consequence, economic models should be constructed so as to yield hypotheses that can be empirically refuted. ${ }^{17}$ Beyond this, however, the Chicago view of the 1950s and 1960s included a belief that the dominant modes of economic theorizing of the day placed too much emphasis on the formal structure and logical coherence of models, and too little on their empirical application and testing. Students in the post-war Chicago department of economics learned that economic theory was a "tool for analyzing a startlingly wide range of concrete problems, rather than an abstract mathematical structure of great beauty but little power" (Friedman 1974). By economic theory was meant the neoclassical theory of competitive markets, built on the foundation provided by Alfred Marshall, whose partial equilibrium mode of analysis was a better tool for building economic science, that is to say, expanding the explanatory reach of neoclassical theory, than the more abstract and formalistic approach exemplified by Walras' general equilibrium theory. ${ }^{18}$

The Chicago economists' commitment to empirical testing of theory (distinct, in their eyes, from the empirical estimation of parameters of a model presumed to be correct), plus their commitment to economic theory of a certain form, led to the development of a particular strategy

\footnotetext{
${ }^{17}$ The phrase "Chicago view" for the approach to economic analysis taught at Chicago in the 1950s and 1960s is from Reder (1982).

${ }^{18}$ The theory of monopoly was also a permissible analytical starting point, but monopoly was assumed to be a relatively rare phenomenon that had little impact on the overall working of the economic system. Theories of imperfect competition, even those based on the optimizing models of Robinson and Chamberlain, were rejected as methodologically unsound and of little practical use. See Friedman (1953, pp. 37-38) and Reder (1982, pp. 15-18).
} 
for dealing with potential empirical puzzles or anomalies. Reder (1982) characterized it this way, using "TP" as an abbreviation for the Chicago approach to economic analysis:

Any apparent inconsistency of findings with the empirical implications of the theory, or report of behavior not implied by the theory, is interpreted as anomalous and requiring one of the following actions: (i) re-examination of the data to reverse the anomalous finding; (ii) redefinition and/or augmentation of the variables in the model, particularly the permissible objects of choice and resource constraints; (iii) alteration of the theory to accommodate behavior inconsistent with the postulates of rationality (constrained optimization) by one or more decision makers (resource owners); (iv) placing the finding on the research agenda as a researchable anomaly...

... Suffice it to say that TP adherents - with variation among individuals - focus attention upon (i) and (ii) and, failing quick resolution of the anomaly, move to (iv) but pay little attention to (iii) . (Reder 1982, p. 13)

Echoes of this Chicago view are obvious in the opening paragraphs of Oi's 1962 paper:

The cyclical behavior of labor markets reveals a number of puzzling features for which there are no truly satisfying explanations . . I I believe that the major impediment to rational explanations for these findings lies in the classical treatment of labor as a purely variable factor. 
In this paper I propose a short-run theory of employment which rests on the premise that labor is a quasi-fixed factor. The fixed employment costs arise from investments by firms in hiring and training activities ...

The concept of labor as a quasi-fixed factor is, in my opinion, the relevant one for a short-run theory of employment. Its implications are amenable to empirical verification and are, in the main, borne out by the available evidence. Thus my theory provides a unified explanation for various aspects of the cyclical functioning of labor markets (Oi 1962, p. 538).

In other words, there are anomalies in the cyclical behavior of labor markets for which there are no "satisfying" or "rational" explanations (meaning explanations that assume optimizing behavior and competitive markets); Oi is proposing such an explanation by adopting Reder's strategy (ii); and his model generates empirically testable hypotheses that he will show to be consistent with empirical data. Interestingly, procyclical labor productivity was not one of the puzzles that motivated Oi. ${ }^{19}$

In Oi's model, firms maximize profit per worker over a multi-period time horizon. There is a fixed cost to hiring a worker and a fixed cost of training each type of worker that raises the marginal product of that type by a known amount. The firm also forms an expected value for the worker's market wage for each future period. Solving the firm's optimization problem led to Oi's first important result "Even under perfect competition wages would be equated to marginal products if and only if labor is a completely variable factor", i.e., if there were no fixed costs of hiring or training. In a long run competitive equilibrium in which neither wage nor value of

\footnotetext{
${ }^{19}$ The puzzles were occupational differences in the stability of employment and earnings, the uneven incidence of unemployment, the persistence of differential labor turnover rates, and discriminatory hiring and firing policies.
} 
marginal product for any type of labor was expected to change, each type of worker's value of marginal product would equal his wage plus the amortized value of the cost of hiring and training him. This wedge between equilibrium wage and marginal product Oi termed the "periodic rent", and the "degree of fixity" of a labor type was the ratio of that labor type's periodic rent to its wage (Oi 1962, p. 541).

Oi then considered the impact on labor demand if a firm in long-run equilibrium learned with certainty of a drop in future product demand, which for a competitive firm meant a drop in future product price $\left(\mathrm{P}^{*}\right)$ and a proportionate drop in value marginal product for each type of worker. Since, for workers already on the payroll, the periodic rent created by hiring and training costs was a sunk cost, the firm would keep a worker on the payroll as long as his per-period marginal product was greater than his per period wage. This led to the result that could be used to explain procyclical labor productivity: The employment of a quasi-fixed factor would only be reduced if the value of marginal product, set above the wage in long run equilibrium by an amount the depended on the worker's degree of fixity, fell below the wage. ${ }^{20}$ The employment of some labor types would not fall at all with a decline in product demand.

Oi worked through several other conjectural shocks to firms in long or short run equilibrium, but as a general matter, Oi's approach to using his model for analysis was much less formal than that of HMMS. For example, he never solved explicitly for an equilibrium path of future employment of a labor type, given a future path of $\mathrm{P}^{*}$. Indeed, it would have been quite difficult for Oi to provide such a derivation, given his assumption of a linear employment adjustment cost, that is, a fixed cost of hiring and training each additional worker. ${ }^{21}$ And this

\footnotetext{
${ }^{20}$ It clear from Oi's discussion of this point that he assumed a neoclassical technology characterized by short run diminishing marginal return to labor (Oi 1962, p. 541).

${ }^{21}$ Oi's linear adjustment cost assumption made the structure of his model similar to that of S, s inventory models, which were beginning to be explored in the operations research literature in the 1950s. However, it was not until
} 
raises another interesting point about the two early formalizations of the labor hoarding concept:

The different decisions made by Oi and the HMMS team about how to represent the cost of adjusting employment reflect their different methodological preferences.

Given the methodological priorities of the HMMS team, a satisfactory model of decision making under uncertainty needed to include mathematical representation of the decision maker's objective function, the constraints he faced, and the nature of his uncertainty about key variables. Also, it was desirable that mathematical expressions for the optimal decision rules could be derived from the model, and were such that the optimal values of the model's choice variables could be estimated by applying existing econometric techniques to existing data. The assumption that labor costs were quadratic in the size of employment change facilitated these goals in two ways. First, it allowed the proof of the certainty equivalence theorem mentioned above. In addition to being an important result for the larger program of developing formal models of decision making under uncertainty, certainty equivalence meant that decision makers only need know the conditional mean of the probability distribution of future demand, which could be plausibly estimated by applying linear regression to past data on demand. Secondly, it meant that the key cost parameters required to implement the optimal decision rules could also be estimated by linear regression from cost data.

For Oi, on the other hand, the approach of assuming a fixed cost of adding each worker to the payroll must have seemed a strong and simple way to explore the implications of relaxing the assumption that labor costs were purely variable costs, increasing linearly with the labor input. Oi's formal analysis of his model essentially ended with his derivation of the model's static equilibrium labor demand functions, functions which differed in potentially interesting ways

Nickell (1978) that the dynamic labor demand functions corresponding to a perfect certainty version of a model like Oi's were derived, and these could not be directly estimated using the regression techniques of the time. 
from those of the basic model. Comparative static analysis of this equilibrium then proceeded using verbal logic, combined with plausibly argued conjectures of how uncertainty might alter the comparative static results. This was enough to serve Oi's goals, as this analysis produced qualitative predictions about the co-movements of key variables that matched some of the "puzzling" cyclical features of labor markets, and also served as the basis for empirical tests of the model. His methodological preferences did not push him towards the derivation of mathematical representations of dynamic labor demand functions, so the fact that the "fixed per worker cost of hiring and training" assumption greatly complicated such a derivation was not a reason to abandon the assumption.

In keeping with the Chicago view discussed above, Oi's empirical goal was to test the implications of his model rather than estimate its parameters. This involved identifying the correlations among observable variables implied by his model, then looking for those correlations in the data using chi-square tests and simple regressions. For example, to test his model's prediction that "factors with the highest degree of fixity and the lowest degree of substitutability with the fixed factor will experience the smallest relative changes in employment due to any change in product demand", Oi first presented information from International Harvester on the costs of hiring and training different classes of workers with different average wage rates, in order to establish that the average wage of a class of workers could serve as an observable proxy for the degree of fixity of that class of workers. Then, using state level data on average wages by occupation from four industries, reported in BLS studies done in 1928 and 1931, he divided all occupations in these industries into high wage and low wage categories, calculated the employment change between the two years for each category, and conducted a chi-square test. The results generally confirmed that the decline in employment in the high wage 
occupations of an industry was smaller than that in the low wage occupations. There was one test in Oi's paper that could have come from the macroeconometric literature of the time: using time series data, he estimated partial adjustment models of employment for production and nonproduction workers. Since the lower-wage production workers would have a lower degree of fixity, Oi reasoned, the estimated partial adjustment parameter from the production worker regression should be higher than that from the non-production worker regression, and indeed it was. Note, however, that the partial adjustment parameter in Oi's regressions was neither derived from nor had any counterpart in Oi's model - it simply measured a correlation needed to test an implication of the model.

\section{Stabilization of the Labor Hoarding Concept}

Although the HMMS model was presented as a normative guide for the optimizing manager, it was picked up quickly by the leading contributors to the macroeconometric literature dealing with the short-run behavior of employment. Soligo (1963) gave a verbal account of the HMMS model, and used it to justify his partial adjustment employment equation. Kuh (1965) cited HMMS as a study of productivity movements over the cycle. Solow (1964) did not refer to HMMS, but, as we have seen, described a similar model of cost-minimization with labor adjustment costs from which he also derived a partial adjustment employment equation. Thus, HMMS provided the macroeconometric research community with a model expressed in a mathematical form that matched their methodological preferences, that portrayed optimizing behavior, and that, when combined with a neoclassical production function, would lead to a short run elasticity of labor with respect to output of less than unity. 
And while Oi did not discuss procyclical labor productivity, the relevance of his model to that topic was quickly recognized by economists who were concerned with the phenomenon, being cited, for example, in Kuh (1965) and Vanderkamp (1966, p. 197). This was not the major impact of Oi's model on economic research, however. More often, it was borrowed or elaborated upon to provide a neoclassical account of some observed labor market phenomenon, thus following the pattern suggested by Friedman (1953, pp. 11-12): "Given that the hypothesis is consistent with the evidence at hand, its further testing involves deducing from it new facts capable of being observed but not previously known and checking these deduced facts against additional empirical evidence." It also appears to me that many economists whose theoretical priors led them to view countercyclical labor productivity as a "puzzle" quickly accepted Oi's model as a solution to the puzzle: countercyclical labor productivity arose from labor hoarding, which arose from optimizing behavior by firms operating in a competitive environment and facing fixed costs of hiring, firing, and training workers.

A good example of both these tendencies is Chicago-trained Sherwin Rosen's (1969) paper offering an explanation of "The Interindustry Wage and Hours Structure". In this paper, Rosen constructed a model of equilibrium in competitive labor markets very much in the Chicago style as described above, in which differences across industries in firm and worker characteristics would lead to different equilibrium levels of wages and hours of work. Rosen noted, citing Oi, that "The novel aspect of the model lies in the demand specification. Certainly there is a great deal of persuasive time series evidence in favor of the view that labor is not an entirely variable factor of production, since there are significant non-wage investment costs associated with it ..."22 . And indeed, the employer's per period cost function in Rosen's model

\footnotetext{
${ }^{22}$ Rosen also cited HMMS, Gary Becker's work on human capital, and the evidence presented by Brechling, Kuh, and Soligo.
} 
included the term $\mathrm{NV}(\mathrm{q}+\mathrm{r})$, where $\mathrm{N}$ was the number of workers, $\mathrm{V}$ was the fixed cost per worker, $\mathrm{q}$ was the retirement rate, and $\mathrm{r}$ the interest rate. In describing how he would convert the implications of his theoretical model into empirically testable hypotheses, Rosen observed that:

Fixed labor costs involve such things as market searching costs, new employee training costs, and opportunity costs associated with on the job experience of the existing work force. These data are not available. Instead, worker attributes commonly associated with labor force quality are used as proxies. Two general observations can be offered as support for this hypothesis. One is labor hoarding during cyclical downturns. The other is occupational upgrading and downgrading during business cycles ... If these attributes were not costly to obtain, firms would have no incentive to engage in such costly practices, and these phenomena could not be explained on the basis of rational behavior. (Rosen 1969, p. 257).

Note the structure of Rosen's logic: labor hoarding is an observed phenomenon, the only rational (i.e. neoclassical) explanation for it is fixed costs of labor correlated with worker quality, therefore such fixed costs must exist. One can easily infer from this how Rosen would have explained procyclical labor productivity.

The HMMS model was more often used by the macroeconometricians actively researching the cyclical behavior of labor productivity and modeling the short and long term relationship between employment and output, and the proper specification and estimation of the labor adjustment cost function as a key structural relationship in macroeconomic models became an important research goal. Early contributors to this literature, however, who acknowledged the 
likely importance of the fixed and adjustment cost elements embodied in Oi's model and the HMMS model, sometimes also offered an alternative explanation for procyclical labor productivity that was rooted in the technology of production rather than the costs associated with hiring labor. This second type of explanation was related to the idea, mentioned by Mitchell in 1951, that modern plants were built to operate at a particular capacity, and that deviations from this level of output in either direction would lead to inefficiency. Okun (1963) had referred to "technological factors" that could lead to short-run productivity declines when output fell below “normal” levels. Solow (1964), as we have seen, distinguished "decreasing cost" explanations for procyclical labor productivity, based on "overhead" labor, from the "labor hoarding" explanations based on costs of changing the level of employment, and the language that he used in describing the decreasing cost explanations suggests that he was including explanations of procyclical labor productivity based on assumptions about indivisibilities in the technology of production.

The two types of explanations - those based on the nature of the short-run production function vs. those based on the nature of the costs of hiring labor - are not mutually exclusive, as Solow noted. Arguably, however, there is a meaningful distinction to be made between the two, notwithstanding Solow's argument about their close relationship. Optimizing behavior plus appropriate assumptions about the nature of the short-run production function could generate the labor productivity patterns uncovered by Hultgren and others even if there were no fixed costs to hiring labor, and optimizing behavior plus fixed costs of hiring labor could generate those patterns even if the short run production function were characterized by diminishing marginal productivity of labor. Only the second scenario, however, was fully consistent with the neoclassical theory of the competitive industry in the short run. 
In any case, technology-based stories were offered along with labor-cost based stories in some of the important contributions to the 1960s literature on the cyclical behavior of productivity and employment (e.g. Soligo 1963, pp. 19, 30-31; Wilson and Eckstein 1964). Ray Fair, however, in his doctoral dissertation on The Short Run Demand for Workers and Hours, took the position that an econometric model that attributed the positive correlation between productivity and output to increasing returns to labor was probably mis-specified (Fair 1969, p. 31). Fair's approach was to assume a fixed proportions short run production function that led to constant returns to labor, and then, to account for procyclical labor productivity, assume that employers usually paid for more labor than they utilized. He justified this second assumption by pointing to Soligo's (1963) description of the fixed costs of labor and the HMMS model, and he developed a procedure for constructing a time series index of this assumed "excess labor". ${ }^{23}$

Fair's hypothesis about excess labor was given something of a twist in later discussions of labor hoarding, with the suggestion that hoarded workers were employed in tasks such as maintenance that did not show up in the firm's measured output. This supposition, which had long been a part of discussions of employer's strategies for dealing with recessions, raised the possibility that at least some of the observed positive correlation between labor productivity and output was due to the mismeasurement of true labor productivity (See McConnell, Brue, and McPherson 1999, p. 545 or Fay and Medoff 1985, p. 639).

In 1985, the Fay and Medoff paper mentioned in the introduction further bolstered the credibility of the modern labor hoarding concept. Hoping to measure directly the excess labor that Fair had assumed to exist, Fay and Medoff sent questionnaires to managers of manufacturing plants asking about their employment decisions during the most recent recession, with questions like "By what percentage was the total number of blue-collar hours paid for

\footnotetext{
${ }^{23}$ Both Solow and Kuh were on Fair's dissertation committee.
} 
actually below normal during the trough quarter (when real shipments were furthest below normal)?" and "If blue collar employment and hours had been cut back to the minimum technically necessary to maintain your plant's actual level of output (and necessary operations) during the downturn, by what percentage would the number of blue-collar hours paid for have been below normal during the trough quarter?" (Fay and Medoff 1985, p. 643, emphasis in original). The authors' chief conclusion from their survey data was that at the trough of the business cycle, the typical plant employed $8 \%$ more labor than was technically necessary to produce its measured output, but that half of that labor was employed in other useful tasks, leaving $4 \%$ of the labor to be classified as truly "hoarded".

Ray Fair reacted quickly to Fay and Medoff's data, with a paper that actually appeared in print six months prior to the publication of the Fay and Medoff paper. Fair applied his own indirect method to measuring excess labor to aggregate data, "to see if the quantitative estimates of Medoff and Fay are consistent with the aggregate evidence.” He went on:

If this is the case, which the results in this paper show, it provides a strong argument in favor of the excess labor hypothesis. Essentially the same conclusion has been reached using two very different data sets. This is one of the few examples in macroeconomics where a hypothesis has been so strongly confirmed using detailed micro data" (Fair 1985, p. 239).

\section{Conclusion}

By the 1990s, the modern labor hoarding concept had come to be widely accepted by economists as the most likely explanation of the observed procyclicality of labor productivity, an 
explanation that was based on the assumption of profit maximization by the firm, and was consistent with the neoclassical model of a competitive industry in short run equilibrium. As far as many economists were concerned, models of labor as a quasi-fixed factor had successfully expanded the explanatory power of neoclassical theory, and assimilated a potential anomaly. ${ }^{24}$

Interestingly, however, the researchers who first produced the convincing evidence that labor productivity was procyclical were not engaged in an attempt to test the basic neoclassical theory of production. The perception of the finding as an important puzzle for neoclassical theory was in large part due to Robert Solow's decision to frame it that way some three years after it first became widely known. The idea that was at the heart of the resolution to the paradox - that costs associated with hiring, firing, and training workers would lead profit maximizing employers to retain more labor than was technically necessary during cyclical downturns in product demand - had been discussed by economists and others for decades as a shrewd business strategy that might also have some social benefits, or, under some circumstances, social costs. About the time that the profession was coming to believe that labor productivity was procyclical this idea was formalized in two influential models, but neither of these two modeling efforts was motivated by a desire to explain the cyclical behavior of labor productivity.

This history of the labor hoarding hypothesis can be seen as a case study of the growth of economic knowledge, by which I mean the set of facts about and explanations of economic phenomena widely accepted among economists. It is not unreasonable for readers of such a case study to ask if there are general lessons about the growth of economic knowledge to be drawn from it. For that reason I will close by offering two observations of a more general nature suggested to me by this case study.

\footnotetext{
${ }^{24}$ However, the argument that increasing returns in production play a role along with labor hoarding in generating procyclical labor productivity remained alive in the 1980s and 1990s (see, for example, Hall 1986).
} 
First, I see a potential parallel between the story presented here and the account offered by Mirowski and Hands (1998) of the emergence of the post-WWII version of the neoclassical theory of consumer demand. Mirowski and Hands (1998) argue that postwar demand theory represents an ensemble of three distinct versions of neoclassical demand theory developed during the interwar period, each associated with a different research tradition, but each, at least in part, motivated by a single theoretical problem with earlier neoclassical models of demand. They submit that the postwar theory of demand was stronger, that is, better able to retain or win adherents, for being an amalgam of these three separate, and in some ways mutually inconsistent, lines of theorizing. Arguably, something similar could be said about the emergence and widespread acceptance of the modern labor hoarding concept. The revision of the theory of labor demand that ultimately came to be accepted as an explanation of countercyclical labor productivity came in two forms, each form reflecting the methodological preferences of a large and influential group of researchers within the emerging neoclassical mainstream. I believe that those who were put off by various shortcoming of one of the formal representations of the labor hoarding process and the empirical evidence that it generated or used to bolster its credibility could be directed to, or direct themselves to, an alternative formal representation that did not have those shortcomings, and that generated or rested upon a different body of empirical evidence that they might regard as more convincing. Arguably, this made it possible for explanations of the workings of labor markets based on the general notion of "labor hoarding" to gain wider assent.

A second observation arises from comparing the long story of the development of the labor hoarding concept presented in the body of this paper to the rather shorter account provided by Fay and Medoff (1985) and described in the introduction. Fay and Medoff's account was 
inaccurate as a historical narrative, but is it possible that it, or accounts like it, still tell us something about the processes by which knowledge grows? I am thinking here of Lakatos' (1970) discussion of the role of rational reconstructions in understanding the growth of scientific knowledge. Lakatos argued, among other things, that the creation of "rational reconstructions" of scientific progress was of primary interest, and that in accounts of the growth of knowledge, one should "relate the internal history in the text, and indicate in the footnotes how actual history misbehaved in the light of its rational reconstruction". ${ }^{25}$ Lakatos grants that there are better and worse rational reconstructions. Indeed, a major purpose of his paper was to illustrate how rational reconstructions should be written, and it is not hard to argue that Fay and Medoff's account falls short as a good rational reconstruction (although again, writing the history of economics was not their purpose). Still, I think that a general point remains. The story of the labor hoarding concept that I have told supports the general proposition that the process by which economic knowledge grows and changes, that is, what we see as we examine the activities and motives of individual economic researchers, is messy. But, as the Fay and Medoff account suggests, a more orderly picture emerges at a higher level of aggregation: an empirical fact was established by the profession, which also ascertained its problematic relationship with a widely accepted body of economic theory, and one element of that theory was amended by the profession in such a way as to provide an explanation of the fact acceptable to adherents to the theory. I am left wondering whether an aggregate process following this pattern has frequently arisen out of a less orderly process at the level of individual research projects and programs, and if so, whether it is worth trying to understand the economics profession, at least over the last century or so, as a set of mechanisms and institutions that generate this pattern.

\footnotetext{
${ }^{25}$ Lakatos (1970) pp. 105, 107. In that light, this paper should be regarded as a very long footnote.
} 


\section{References}

Barber, William J. From New Era to New Deal: Herbert Hoover, the Economists, and American Economic Policy, 1921-1933. Cambridge UK: Cambridge University Press, 1985.

Biddle, Jeff E. Social Science and the Making of Social Policy: Wesley Mitchell's Vision. Pp. 43-79 in The Economic Mind in America: Essays in the History of American Economics, ed. Malcolm Rutherford. London: Routledge 1998.

Brechling, F. P. R. The Relationship Between Output and Employment in British Manufacturing Industries. The Review of Economic Studies, Vol. 32, No. 3 (Jul., 1965), pp. 187-216

Brown, A. J. Inflation and the British Economy. The Economic Journal, Vol. 68, No. 271 (Sep., 1958), pp. 449-463

Burns, Arthur F. Introductory Sketch. pp. 1-54 in Wesley Clair Mitchell: The Economic Scientist, ed. Arthur Burns. New York: NBER, 1952

and Wesley C. Mitchell. Measuring Business Cycles. New York: NBER, 1946.

Clark, J. M. Studies in the Economics of Overhead Costs. Chicago: University of Chicago Press, 1923. 
Dornbusch, Rudiger and Stanley Fischer. Macroeconomics, $2^{\text {nd }}$ Edition. New York: McGraw Hill, 1981.

Douglas, Paul. Personnel Problems and the Business Cycle. Administration.Vol. IV, no. 1, (July 1922), pp. 15-27.

Dunlop, John T. The Movement of Real and Money Wage Rates. The Economic Journal, Vol. 48, No. 191 (Sep., 1938) pp. 413-434.

Fabricant, Solomon. Basic Facts on Productivity Change. Occasional Paper 63. New York: NBER, 1959

Fair, Ray C. Excess Labor and the Business Cycle. American Economic Review, Vol. 75, No. 1 (Mar., 1985), pp. 239-245.

. The Short Run Demand for Workers and Hours. Amsterdam: North Holland, 1969.

Fay, Jon A. and James Medoff. Labor and Output over the Business Cycle: Some Direct Evidence. American Economic Review, Vol. 75, No. 4 (Sept., 1985), pp. 638-655.

Flanagan, Robert J., Robert S. Smith and Ronald G. Ehrenberg. Labor Economics and Labor Relations. Glenview, Il: Scott, Foresman, and Co., 1984 
Friedman, Milton. Schools at Chicago. In The Indispensible Milton Friedman. Ed. by Lanny Ebenstein. Washington DC: Regnery, 2012 [1974], pp. 25-36.

. The Methodology of Positive Economics. In Essays in Positive Economics.

Chicago: University of Chicago Press, 1953, pp. 3-43.

Goodwin, Craufurd. Walter Lippmann: The Making of a Public Economist. History of Political Economy, vol. 45, no. suppl. 1, 2013, pp. 92-113.

Haavelmo, Trygvee. The Probability Approach in Econometrics. Econometrica, Vol. 12, Supplement (Jul., 1944), pp. iii-115

Haber, William. Manpower and Employment Problems in Transition from War to Peace. The Review of Economics and Statistics, Vol. 26, No. 2 (May, 1944), pp. 57-68

Hall, R. L. and C. J. Hitch. Price Theory and Business Behavior. Oxford Economic Papers, Vol. 2 (May 1939), pp. 12-45.

Hamermesh, Daniel and Albert Rees. The Economics of Work and Pay, $3^{\text {rd }}$ Edition. New York: Harper and Rowe, 1984. 
Hammond, J. Daniel. The Development of Post-War Chicago Price Theory. In The Elgar Companion to the Chicago School of Economics. Ed. by Ross Emmett. Cheltenham: Edward Elgar, 2010.

Holt, Charles C., Franco Modigliani, John Muth, and Herbert Simon. Planning Production, Inventories, and Work Force. Englewood Cliffs, NJ: Prentice-Hall, 1960.

Hultgren, Thor. American Transportation in Prosperity and Depression. New York: NBER, 1948.

. Changes in Labor Costs during Cycles of Production and Business. New York:

NBER, 1960.

Jerome, Harry. Mechanization in Industry. New York: National Bureau of Economic Research, 1934.

Kuh, Edwin. Cyclical and Secular Labor Productivity in United States Manufacturing. The Review of Economics and Statistics, Vol. 47, No. 1 (Feb., 1965), pp. 1-12 . Profits, Profit Markups, and Productivity. Study Paper No. 15 of the Joint Economic Committee Study of Employment, Growth, and Price Levels. Washington: USGPO, 1960 
Lakatos, Imre. History of Science and its Rational Reconstructions. PSA: Proceedings of the Biennial Meeting of the Philosophy of Science Association. Vo. 1970 (1970). Pp. 91-136.

Lippmann, Walter. Today and Tomorrow: Agitation and Work. New York Herald Tribune, Oct. $6,1936$.

McConnell, Campbell and Stanley Brue. Contemporary Labor Economics. New York: McGraw Hill ( $1^{\text {st }}$ edition, 1986; $2^{\text {nd }}$ Edition, 1989: $5^{\text {th }}$ Edition, with David A MacPherson, 1999).

Means, Gardiner. Price Inflexibility and the Requirements of a Stabilizing Monetary Policy. Journal of the American Statistical Association, Vol. 30 (June 1935), pp. 401-413.

Mills, Frederick. Changes in Physical Production, Industrial Productivity and Manufacturing Costs, 1927-1932. NBER Bulletin 45, February 23, 1933.

Mirowski, Philip and D. Wade Hands. A Paradox of Budgets: The Postwar Stabilization of Neoclassical Demand Theory. History of Political Economy, Volume 30, Supplement (1998), pp. $260-292$

Mitchell, Wesley. Business Cycles. Berkeley: University of California Press, 1913. . What Happens During Business Cycles: A Progress Report. New York: NBER, 1951. 
National Bureau of Economic Research. Report of the Executive Director for 1937. New York: NBER, 1938 (accessed at http://papers.nber.org/books/unkn38-3)

Neild, R. R. Pricing and Employment in the Trade Cycle. Occasional Paper XXI of the National Institute of Economic and Social Research. Cambridge UK: Cambridge University Press, 1963.

Nickell, S. J. Fixed Costs, Employment, and Labour Demand over the Cycle. Economica, New Series, vol. 45, no. 180 (Nov. 1978), pp. 329-345.

Oi, Walter. Labor as a Quasi-Fixed Factor. Journal of Political Economy, Vol 70, no. 6 (December 1962), pp. 538-555

Okun, Arthur. Potential GNP: Its Measurement and Significance. Cowles Foundation Paper No. 190 (reprinted from the 1962 Proceedings of the Business and Economics Statistics Section of the American Statistical Association) 1963. (accessed at http://cowles.econ.yale.edu/P/cp/py1963.htm)

Oxenfeldt, Alfred R. and Ernest van den Haag . Unemployment in Planned and Capitalist Economies. The Quarterly Journal of Economics, Vol. 68, No. 1 (Feb., 1954), pp. 43-60.

Rancan, Antonella. Modigliani's and Simon's Early Contributions to Uncertainty. History of Political Economy, Vol. 45, No. 1 (Spring 2013), pp. 1-38. 
Reder, Melvin. Chicago Economics: Permanence and Change. Journal of Economic Literature, Vol. 20, No. 1 (Mar., 1982), pp. 1-38

Rosen, Sherwin. On the Interindustry Wage and Hours Structure. Journal of Political Economy, Vol. 77, No. 2 (Mar. - Apr., 1969), pp. 249-273.

Siegel, Irving. Labor Productivity in the Soviet Union. Journal of the American Statistical Association, Vol. 48, No. 261 (Mar., 1953), pp. 65-78

Soligo, Ronald. The Short Run Relationship between Employment and Output. Dissertation. Yale University, 1963. United States -- Connecticut: ProQuest. Web. 25 Mar. 2013.

Solow, Robert. Draft of Presidential Address on the Short Run Relation of Employment and Output. Robert Solow papers, David M. Rubenstein Rare Book \& Manuscript Library, Duke University. Box 70, Folder 1964, dated 1964.

Stone, N. I. Methods of Stabilizing Production of Textiles, Clothing, and Novelties. Pp. 118-135 in Business Cycles and Unemployment, ed. Committee of the President's Conference on Unemployment, and a Special Staff of the National Bureau. New York: NBER, 1923.

Tarshis, Lorie. Changes in Real and Money Wages. The Economic Journal, Vol. 49, No. 193 (Mar., 1939), pp. 150-154. 
Vandercamp, John. Wage and Price Determination: An Empirical Model for Canada.

Wilson, Thomas A, and Otto Eckstein. Short-Run Productivity Behavior in U.S. Manufacturing.

The Review of Economics and Statistics, Vol. 46, No. 1 (Feb., 1964), pp. 41-54

Woirol, Gregory R. New Data, New Issues. The Origins of the Technological Unemployment

Debate. History of Political Economy, Vol. 38, no. 3 (Fall 2006), pp. 473-496. 